\title{
Blood Ketones and HbA1c - Pan-India Report on Values, Trends and Outcome
}

\author{
Caesar Sengupta, Sandhya Iyer*, Velumani A, Amruta V, Prachi Sinkar
}

Biochemistry Division, Thyrocare Technologies Limited, Plot No.D37/1,TTC Industrial area, MIDC, Turbhe, Navi Mumbai - 400703, India.

\begin{abstract}
Objectives: Glycated hemoglobin analysis is the gold-standard to guide diabetes management and screening for diabetic ketoacidosis. Though testing for A1c is a recommendation, correlation with ketone levels has been studied using many variables like fasting blood glucose, mean glucose levels, etc. Our study report is an attempt to document blood ketone levels in relation to measured A1c levels. Study Design: This is a retrospective reference lab-based study. Methods: A total of 429,051 adults including 234,121 males and 194,930 females were tested for HbA1c as well blood ketone levels. Measurement for A1c was done using High Performance Liquid Chromatography, while blood ketones were assessed by photometry technology. Results: Outcome analysis was done by assessing for levels of blood ketone across different $\mathrm{HbA} 1 \mathrm{c}$ reporting criteria of normal and good control up until the poor control range of $>10.0 \%$ $(86 \mathrm{mmol} / \mathrm{mol})$. Trend analysis to study relation between $\mathrm{HbA} 1 \mathrm{c}$ and ketone levels detected, a significant positive association between A1c levels $>/=15.0 \%(140 \mathrm{mmol} / \mathrm{mol})$ and blood ketone levels. Conclusion: Our report highlights A1c levels of $>15.0 \%(140 \mathrm{mmol} / \mathrm{mol})$ to be a significant cut-off to identify patients at risk for diabetic ketoacidosis.
\end{abstract}

Keywords: Glycated hemoglobin, India, Blood ketones, Ketoacidosis

\footnotetext{
Editor $\mid$ Muhammad Nauman Zahid, Quality Operations Laboratory, University of Veterinary and Animal Sciences, Lahore, Pakistan.

Received | January 12, 2019 Accepted | February 22, 2019; Published | April 01, 2019

*Correspondence | Sandhya Iyer, Biochemistry Division, Thyrocare Technologies Limited, Plot No.D37/1,TTC Industrial area, MIDC, Turbhe, Navi Mumbai - 400703, India; Email: sandhya.iyer@thyrocare.com

Citation | Sengupta C, Iyer S, Velumani A, Amruta V, Sinkar P (2019). Blood ketones and hba1c - pan-india report on values, trends and outcome. S. Asian J. Life Sci. 7(1): 19-24.

DOI | http://dx.doi.org/10.17582/journal.sajls/2019/7.1.19.24

ISSN | 2311-0589
}

Copyright (C) 2019 Sengupta et al. This is an open access article distributed under the Creative Commons Attribution License, which permits unrestricted use, distribution, and reproduction in any medium, provided the original work is properly cited.

\section{INTRODUCTION}

$G$ lycated hemoglobin (HbA1c) analysis which indicates an average of blood glucose levels over the past two - three months is considered to be the gold standard for monitoring chronic glycemia among individuals with diabetes (Nathan, et al., 2007). The potential to use A1c monitoring as an efficient clinical tool for monitoring risk for complications has also been published by the United Kingdom Prospective Diabetes Study and the Diabetes Control and Complications Trial (DCCT) (Kilpatrick, 2008). A1c values have also been associated with identifying risk of diabetes-associated complications like diabetic retinopathy and nephropathy (Penno et al., 2013; Kawasaki et al., 2011; Waden et al., 2009). Thus HbA1c is concluded to be an in- tegrated measure for glycemic variations from normoglycemia to hypoglycemia as well as fasting and post prandial hyperglycemia (Makris and Spanou, 2011). A1c has also been included as a recommendation criteria for diagnosis of diabetes mellitus (International Expert Committee, 2009). Diabetic ketoacidosis (DKA), a preventable life-threatening diabetes-associated complication which highlights severe insulin deficiency is documented to cause adverse neurocognitive outcomes and its presence during diagnosis of Type 1 diabetes is considered to be a marker of poor metabolic state and depleted beta cell reserve (Fernandez et al., 1996). In case of Type 2 diabetes, DKA is increasingly being recognized as an initial manifestation (Umpierrez et al., 1999). It generally follows absolute or relative insulin deficiency which results in lipolysis and ketogene- 
sis. Though buffered initially, ketone bodies are acidic and hence at increased levels results in acidosis. The block in identifying DKA is the lack of apparent diagnosis apart from conflicting criteria like hyperglycemia not been seen in all cases and also detection of low blood ketones as well ( $<3 \mathrm{mmol} / \mathrm{L}$ ) (Misra and Oliver, 2015). Studies involved in documenting relation between DKA and $\mathrm{HbA1c}$, have identified presentation of this acute metabolic complication of diabetes to be co-occurring with high $\mathrm{HbA} 1 \mathrm{c}$ levels. Thus DKA has been postulated to occur in the background of chronic hyperglycemia in existing as well as newly diagnosed cases (Ekpebegh et al., 2014). Further studies which have assessed DKA at diagnosis of Type 1 diabetes have identified sustained negative effect of the same on glycemic control in affected children during the following period of 15 years. This study also highlighted DKA beyond an acute complication of diabetes as a harbinger of high morbidity and mortality associated with poor glycemic control. A multivariate analysis in the same study also identified DKA at diagnosis to predict elevated longitudinal HbA1c levels independently (Duca et al., 2017).

Many studies though have assessed relation between DKA and high $\mathrm{HbA1c}$ levels; very few have actually identified a strong A1c cut-off value to identify definitive risk of acidosis. A recent study on $\mathrm{HbA1c}$ as a screening tool for patients with type 2 diabetes mellitus identified probability of ketosis to concur with $\mathrm{HbA} 1 \mathrm{c}$ values of $>/=10.1 \%$ among the newly diagnosed, and at $>/=8.6 \%$ among previously diagnosed (Zhu et al., 2016). Determining population specific A1c cut-off values for risk of ketosis also becomes an asset for clinical management and our report is an attempt to present the same in a large pan-India cohort of over 4 lakh individuals tested.

\section{METHODS}

\section{Study Design}

This is a retrospective study involving analysis of data collected at our reference lab through samples referred for routine testing.

\section{STUdy CoHorT}

Data from a total of 429,051 individuals tested for HbA1c and blood ketones including 234,121 males and 194,930 females were included for the analysis. This retrospective analysis did not involve any informed consent declaration as the samples were tested in a reference laboratory and not a hospital-based set up. Apart from gender, no other patient identifiers were used in this study. Further cohort characteristics have been highlighted in Table 1 .

\section{Estimation of HbA1c and Blood Ketones}

EDTA whole blood was used for estimation of HbA1c us- ing the analytical technology of High Performance Liquid Chromatography (HPLC; Biorad Variant II Turbo). The technique involves use of a cation exchange column and a gradient elution with three fluid steps using buffers with different salt concentrations. The run time for each sample was set at 1.6 minutes and the absorbance measured at $415 \mathrm{~nm}$. For quality control, dedicated Biorad analytical controls (Hercules, CA) were tested with each analytical run and involved two ranges; low and high. The long term quality performance was also assessed by the LJ plots to check for trends and deviations.

Table 1: Cohort characteristics

\begin{tabular}{|c|c|c|c|c|}
\hline Cohort & $\mathbf{N}$ & $\begin{array}{l}\text { Mean } \\
\text { Age } \\
\text { (Years) }\end{array}$ & $\begin{array}{l}\text { Mean } H b A 1 c \\
\text { values }(\%)\end{array}$ & $\begin{array}{l}\text { Median } \\
\text { blood ketone } \\
\text { values } \\
(\mathrm{mg} / \mathrm{dL})\end{array}$ \\
\hline Males & 234121 & $\begin{array}{l}47+/- \\
14\end{array}$ & $\begin{array}{l}6.6+/-1.7 \\
(49 \mathrm{mmol} / \mathrm{mol})\end{array}$ & 0.3 \\
\hline Females & 194930 & $\begin{array}{l}47+/- \\
14\end{array}$ & $\begin{array}{l}6.3+/-1.6 \\
(45 \mathrm{mmol} / \mathrm{mol})\end{array}$ & 0.3 \\
\hline Total & 429051 & $\begin{array}{l}47+/- \\
14\end{array}$ & $\begin{array}{l}6.5+/-1.6 \\
(48 \mathrm{mmol} / \mathrm{mol})\end{array}$ & 0.3 \\
\hline
\end{tabular}

Estimation of blood ketone was done using serum and the technology of photometry (Advia 2400) was used. The beta-hydroxybutyrate assay kit (Beijing Strong Biotechnologies, Inc. China) was used for testing. The assay works on enzymatic oxidation of D-3-hydroxybutyrate to acetoacetate along with concomitant reduction of cofactor $\mathrm{NAD}+$ to NADH. Associated change in absorbance is the correlated to D-3-hydroxybutyrate concentration. Quality control assay involved use of Randox Assayed Multi-sera.

\section{RESULTS}

Analysis of relation between $\mathrm{HbA1c}$ values and blood ketone levels was done considering the reporting ranges of the former. Blood ketone values of $0.21-2.81 \mathrm{mg} / \mathrm{dL}$ is considered to be normal for reporting. Frequency analysis of different $\mathrm{HbA} 1 \mathrm{c}$ reporting groups with the average blood ketone levels have been represented in Table 2 .

Further, trend analysis was also done for each of the HbA1c reporting groups in relation to blood ketone levels of that specific cohort. For the HbA1c values in ranges of Normal, Good control, Fair control and Unsatisfactory control, no significant trend was observed between A1c and blood ketone values. For the poor control indicating A1c values above $10.0 \%(86 \mathrm{mmol} / \mathrm{mol})$, a slight positive trend was noted though not significant. To identify a specific HbA1c cut-off value of significance in relation to blood ketone values, another trend analysis of $\mathrm{HbA} 1 \mathrm{c}$ values above $15.0 \%$ $(140 \mathrm{mmol} / \mathrm{mol})$ was done. This trend was detected to be 
Table 2: Frequency in different $\mathrm{HbA1c}$ reporting groups

\begin{tabular}{|c|c|c|c|c|}
\hline HbA1c Reporting & $\begin{array}{l}\text { Total } \\
\text { Frequency (\%) }\end{array}$ & $\begin{array}{l}\text { Males } \\
\text { Frequency (\%) }\end{array}$ & $\begin{array}{l}\text { Females } \\
\text { Frequency (\%) }\end{array}$ & Statistical significance \\
\hline Normal $(<6.0 \% ; 42 \mathrm{mmol} / \mathrm{mol})$ & 56.0 & 53.0 & 60.0 & No significance \\
\hline $\begin{array}{l}\text { Good control }(6.0-7.0 \% ; 42-53 \\
\mathrm{mmol} / \mathrm{mol})\end{array}$ & 22.0 & 22.0 & 22.0 & No significance \\
\hline $\begin{array}{l}\text { Fair control }(7.0-8.0 \% ; 53-64 \\
\mathrm{mmol} / \mathrm{mol})\end{array}$ & 8.6 & 9.7 & 7.2 & $\begin{array}{l}\text { Significant at } p<0.05 \text { by two- } \\
\text { tailed } Z \text { test }\end{array}$ \\
\hline $\begin{array}{l}\text { Unsatisfactory control }(8.0-10.0 \% \text {; } \\
64-86 \mathrm{mmol} / \mathrm{mol})\end{array}$ & 8.2 & 9.5 & 6.6 & $\begin{array}{l}\text { Significant at } p<0.05 \text { by two- } \\
\text { tailed } Z \text { test }\end{array}$ \\
\hline Poor control (> 10.0\%; $86 \mathrm{mmol} / \mathrm{mol})$ & 5.1 & 5.8 & 4.3 & $\begin{array}{l}\text { Significant at } p<0.05 \text { by two- } \\
\text { tailed } Z \text { test }\end{array}$ \\
\hline
\end{tabular}

Table 3: Frequency analysis of blood ketone levels

\begin{tabular}{llllll}
$\begin{array}{l}\text { Beta Ketone } \\
\text { levels }\end{array}$ & $\begin{array}{l}\text { Total } \\
\text { Frequency (\%) }\end{array}$ & $\begin{array}{l}\text { Males } \\
\text { Frequency (\%) }\end{array}$ & $\begin{array}{l}\text { Females } \\
\text { Frequency (\%) }\end{array}$ & $\begin{array}{l}\text { Statistical significance } \\
\text { Significant at } \mathrm{p}<0.05 \text { by }\end{array}$ & Mean HbA1c values (\%) \\
\hline $0.21 \mathrm{mg} / \mathrm{dL}$ & 30.0 & 26.0 & 34.0 & $\begin{array}{l}6.1+/-1.1 \\
(43 \mathrm{mmol} / \mathrm{mol})\end{array}$ \\
\hline $2.81 \mathrm{mg} / \mathrm{dL}$ & 2.0 & 2.3 & 1.5 & $\begin{array}{l}\text { Significant at } \mathrm{p}<0.05 \text { by } \\
\text { two-tailed } Z \text { test }\end{array}$ & $\begin{array}{l}7.3+/-2.8 \\
(56 \mathrm{mmol} / \mathrm{mol})\end{array}$ \\
\hline
\end{tabular}

Table 4: A1c clinical ranges with average blood ketone and statistical significance

\begin{tabular}{lllll}
$\begin{array}{l}\text { Sr. } \\
\text { No }\end{array}$ & HbA1c levels & $\begin{array}{l}\text { Median blood ketone } \\
(\mathbf{m g} / \mathbf{d L})\end{array}$ & $\begin{array}{l}\text { IQR for blood ketone } \\
(\mathbf{m g} / \mathbf{d L})\end{array}$ & Significance \\
\hline 1 & $\begin{array}{l}<6.0 \% \\
(42 \mathrm{mmol} / \mathrm{mol})\end{array}$ & 0.2 & No \\
\hline 2 & $\begin{array}{l}6.0 \%-7.0 \% \\
(42-53 \mathrm{mmol} / \mathrm{mol})\end{array}$ & 0.3 & 0.3 & No \\
\hline 3 & $\begin{array}{l}7.0 \%-8.0 \% \\
(53-64 \mathrm{mmol} / \mathrm{mol})\end{array}$ & 0.4 & 0.3 & No \\
\hline 4 & $\begin{array}{l}8.0 \%-10.0 \% \\
(64-86 \mathrm{mmol} / \mathrm{mol})\end{array}$ & 0.4 & 0.4 & No \\
\hline 5 & $\begin{array}{l}10.0 \%-15.0 \% \\
(86-140 \mathrm{mmol} / \mathrm{mol})\end{array}$ & 0.5 & 0.6 & No \\
\hline 6 & $\begin{array}{l}>15.0 \% \\
(140 \mathrm{mmol} / \mathrm{mol})\end{array}$ & 1.4 & 3.2 & Significant at $\mathrm{p}<0.05$ \\
\hline
\end{tabular}

statistically significant by linear regression analysis $\mathrm{F}(1,584)=12.2, \mathrm{p}<0.05$. Also, Odds ratio analysis among males between the A1c value $>/=10.0 \%(86 \mathrm{mmol} / \mathrm{mol})$ and $>/=15.0 \%(140 \mathrm{mmol} / \mathrm{mol})$ detected the odds to be 1.1 (95\% CI: 0.9 to 1.3 ) while among females it was low at 0.9 (95\% CI: 0.8 to 1.1 ).

Further analysis on frequency of high and low blood ketone was also done in relation to mean $\mathrm{HbA1c}$ levels in these cohorts. The outcome has been highlighted in Table 3. Trend analysis did not yield any significant observations. The relationship between different A1c clinical reference ranges and the associated blood ketone averages have been summarized in Table 4.

January-June 2019 | Volume 7 | Issue 1 | Page 21

\section{DISCUSSION}

DKA which is a major metabolic complication has been widely studied in relation to type 1 diabetes and has been widely reviewed in published literature as well. Diagnosis of DKA involves three biochemical indications like ketones in serum or urine, elevated plasma glucose ( $>250$ $\mathrm{mg} / \mathrm{dL}$ ) and acidosis (Eledrisi et al., 2006). Studies which focus on reporting inpatient mortality rates for DKA have identified the frequency to be low at $<1 \%$ in Scotland and USA, while in India, the reported cases account for about 30\% (Gibb et al., 2016; Kitabchi et al., 2009; Agarwal et al., 2016). Thus opposed to popular belief majority cases of DKA occurs among the established patients, while only about 1 in 10 occur among the undiagnosed (Laffel, 2007). Further, though prevalence of DKA during disease pres- 
entation is well documented among pediatric cases, among adults it largely remains unexplored. Detection of high frequency of DKA has been attributed to many risk factors like high mean HbA1c levels, young age, low physical activity and socioeconomic status, certain infections as well as psychological ailments (Butalia et al., 2013; Lebenthal et al., 2012; Bohn et al., 2015; Trief et al., 2014). Prevalence of DKA has also been published with relevance to $\mathrm{HbA1c}$ values, wherein high incidence has been recorded among patients with fair or poor glycemic control i.e HbA1c $>/=$ $8.5 \%$, while lowest prevalence being among patients with good glycemic control i.e HbA1c $<6.5 \%$ (Simmons et al., 2013). With this background, our study was aimed at determining the $\mathrm{HbA} 1 \mathrm{c}$ cut-off values among Asian Indians to predict risk towards development of DKA.

Our report which has been generated after analyzing test outcomes from a cohort of 429,051 Asian Indians has identified the frequency of poor control cases i.e those exhibiting $\mathrm{HbA} 1 \mathrm{c}>10.0 \%(86 \mathrm{mmol} / \mathrm{mol})$ to be $5.1 \%$. The frequency among males was higher at $5.8 \%$ as compared to females at $4.3 \%$ and this difference was statistically significant at $\mathrm{p}<0.05$. Though poor control as a status only explains glycemic control and outcome of diabetes management strategies in place, many studies across different population groups from India have recorded different HbA1c cut-off for detecting diabetes. Published studies from North and South regions of the country together highlight HbA1c values $>/=6.0-6.4 \%$ to be the optimal cut-off (Snehalatha et al., 2000; Kumar et al., 2010). Another study, which worked on reporting $\mathrm{HbA1c}$ values for defining diabetes and impaired fasting glucose among Asian Indians detected the cut-off values to be much lower at $>/=5.8 \%$ for the newly diagnosed individuals with diabetes (Nair et al., 2011). In our report though analysis has been done based on clinical diagnostic reporting ranges for classifying status of glycemic control, the comparison with blood ketones aids in identifying true at-risk cohort for ketoacidosis, for which one of the proven risk factor is high mean HbA1c levels.

Blood ketone analysis done in our cohort considering clinical range of between $0.21-2.81 \mathrm{mg} / \mathrm{dL}$, identified $2.0 \%$ to be the frequency among those harboring high and the frequency among males was higher at $2.3 \%$ compared to females at $1.5 \%$ with the difference being statistically significant at $\mathrm{p}<0.05$. The mean $\mathrm{HbA} 1 \mathrm{c}$ level in this cohort was detected to be $7.3+/-2.8 \%(56+/-9 \mathrm{mmol} / \mathrm{mol})$. Ketone analysis in urine has some inherent drawbacks wherein estimation includes only acetoacetate and acetone but not beta-hydroxybutyrate levels of which have shown the best decline post successful insulin and rehydration therapy corresponding well with the overall ketone concentration trend. This can lead to misinterpretation causing unnecessary overtreatment. Further, testing for the same has also been shown to be highly hydration dependent, thereby passing on the onus to the patient involved (Laffel, 2007). However, in our assay, analysis of blood ketones has been done which estimates the D-3-hydroxybutyrate in serum and plasma. Since D-3-hydroxybutyrate accounts for $75 \%$ of the ketone bodies during periods of ketosis, its levels have been shown to rise much higher than the other two; acetoacetate and acetone (McMurray et al., 1984). Thus, we overcome the inherent flaw of the urine ketone testing assay.

Comparison between different HbA1c levels and trend in blood ketone values, detected a significant positive correlation from $\mathrm{HbA} 1 \mathrm{c}$ values of $>/=15.0 \%(140 \mathrm{mmol} / \mathrm{mol})$. Though this value looks clinically high, it still indicates a trend which cannot be overlooked among adults with diabetes. For $\mathrm{HbA} 1 \mathrm{c}$ values of $>/=10.0 \%(86 \mathrm{mmol} / \mathrm{mol})$, though a weak positive correlation was noted, statistical strength was detected to be drawn only for A1c values of $>/=15.0 \%(140 \mathrm{mmol} / \mathrm{mol})$. However, the adjusted OR ( $95 \% \mathrm{CI}$ ) between males in the $>/=10.0 \%(86 \mathrm{mmol} /$ mol) HbA1c group and $>/=15.0 \%(140 \mathrm{mmol} / \mathrm{mol}) \mathrm{A} 1 \mathrm{c}$ group was 1.1 (95\% CI: 0.9 to 1.3). In case of females, lower odds were however detected at 0.9 (95\% CI: 0.8 to 1.1). However, the $>/=15.0 \%$ analysis cohort did exhibit significant linear regression at $\mathrm{p}<0.05$. One Nature report which has analyzed $\mathrm{HbA} 1 \mathrm{c}$ as a screening tool for ketosis in patients with type 2 diabetes mellitus, documented A1c levels correlation with ketosis. This retrospective analysis of 253 type 2 diabetes affected with ketosis and a control group of 221 without ketosis detected ketosis to be a likely probable event at HbA1c values of $>/=10.1 \%$ for the newly diagnosed, while values of $>/=8.6 \%$ among patients with previous diagnosis (Zhu et al., 2016).

\section{CONCLUSION}

Our report is one of the first few to document an HbA1c cut-off value of $>/=15.0 \%(140 \mathrm{mmol} / \mathrm{mol})$ as risk for ketosis in a large pan-India cohort of over 4 lakh individuals. Though our study carries the inherent drawback of not knowing percentage of type 1 and type 2 diabetes affected individuals in the cohort, $\mathrm{HbA} 1 \mathrm{c}$ does remain a measure for glycemic management among both and DKA a highrisk preventable complication.

\section{Limitations of THE Study}

The authors would like to highlight the following drawbacks of this study;

Type I and II diabetes was not differentiated for analysis Only D-3-hydroxybutyrate blood ketone was measured 


\section{CONFLICT OF INTEREST}

There is no conflict of interest.

\section{ETHICAL APPROVAL}

The data used for analysis was generated in a reference lab and not a hospital-based setting. No patient identifiers except gender have been used. The authors declare that no experiments were performed on humans or animals for this investigation. The author's declare that no patient data appears in this article.

\section{AUTHORS CONTRIBUTION}

All authors contributed equally.

\section{REFERENCES}

- Agarwal A, Yadav A, Gutch M, Consul S, Kumar S, Prakash V, Gupta AK, Bhattacharjee A (2016). Prognostic factors in patients hospitalized with diabetic ketoacidosis. Endocrinol. Metab. 31(3): 424 - 432. https://doi.org/10.3803/ EnM.2016.31.3.424

- Bohn B, Herbst A, Pfeifer M, Krakow D, Zimny S, Kopp F, Melmer A, Steinacker JM, Holl RW (2015). Impact of physical activity on glycemic control and prevalence of cardiovascular risk factors in adults with type 1 diabetes: A cross-sectional multicenter study of 18,028 patients. Diabet. Care. 38(8): 1536 - 1543. https://doi.org/10.2337/dc150030

- Butalia S, Johnson JA, Ghali WA, Rabi DM (2013). Clinical and socio-demographic factors associated with diabetic ketoacidosis hospitalization in adults with type 1 diabetes. Diabet Med. 30(5): 567 - 573. https://doi.org/10.1111/ dme.12127

- Duca LM, Wang B, Rewers M, Rewers A (2017). Diabetic ketoacidosis at diagnosis of type 1 diabetes predicts poor long-term glycemic control. Diabet. Care. 40(9): 1249 1255. https://doi.org/10.2337/dc17-0558

- Ekpebegh CO, Longo-Mbenza B, Blanco-Blanco E (2014). Glycosylated hemoglobin is markedly elevated in new and known diabetes patients with hyperglycaemic ketoacidosis. Afr. Health Sci. 14(3): 526 - 532. https://doi.org/10.4314/ ahs.v14i3.5

- Eledrisi MS, Alshanti MS, Shah MF, Brolosy B, Jaha N (2006). Overview of the diagnosis and management of diabetic ketoacidosis. Am. J. Med. Sci. 331(5): 243 - 251.

- Fernandez CM, Montana E, Camps I, Biarnes J, Merino JF, Escriba JM, Nacher V, Rosel P, Soler J (1996). Ketoacidosis at diagnosis is predictive of lower residual beta-cell function and poor metabolic control in type 1 diabetes. Diabet. Metab. 22(5): $349-355$.

- Gibb FW, Teoh WL, Graham J Lockman KA (2016). Risk of death following admission to a UK hospital with diabetic ketoacidosis. Diabetologia. 59(10): 2082 - 2087. https://doi. org/10.1007/s00125-016-4034-0

- International Expert Committee (2009). International Expert Committee report on the role of the $\mathrm{A} 1 \mathrm{C}$ assay in the diagnosis of diabetes. Diabet. Care. 32(7): 1327 - 1334. https://doi.org/10.2337/dc09-9033

- Kawasaki R, Tanaka S, Tanaka S, Yamamoto T, Sone H, Ohashi Y, Akanuma Y, Yamada N, Yamashita H (2011). Incidence and progression of diabetic retinopathy in Japanese adults with type 2 diabetes: 8 year follow-up study of the Japan Diabetes Complications Study (JDCS). Diabetologia. 54(9): 2288 - 2294. https://doi.org/10.1007/s00125-011-2199-0

- Kilpatrick ES (2008). Haemoglobin A1c in the diagnosis and monitoring of diabetes mellitus. J. Clin. Pathol. 61(9): 977 982. https://doi.org/10.1136/jcp.2007.054304

- Kitabchi AE, Umpierrez GE, Miles JM, Fisher JN (2009). Hyperglycemic crises in adult patients with diabetes. Diabet. Care. 32(7): 1335 - 1343. https://doi.org/10.2337/dc099032

- Kumar PR, Bhansali A, Ravikiran M, Bhansali S, Dutta P, Thakur JS, Sachdeva N, Bhadada SK, Walia R (2010). Utility of glycated hemoglobin in diagnosing type 2 diabetes mellitus: a community-based study. J. Clin. Endocrinol. Metab. 95(6): 2832 - 2835. https://doi.org/10.1210/ jc. 2009-2433

- Laffel L (2007). Improving outcomes with POCT for HbA1c and blood ketone testing. J. Diabet. Sci. Technol. 1(1): 133 136. https://doi.org/10.1177/193229680700100122

- Lebenthal Y, Shalitin S, Yackobovitch-Gavan M, Phillip M, Lazar L (2012). Retrospective comparative analysis of metabolic control and early complications in familial and sporadic type 1 diabetes patients. J. Diabet. Complicat. 26(3): 219 - 224. https://doi.org/10.1016/j.jdiacomp.2012.03.016

- Makris K, Spanou L (2011). Is there a relationship between mean blood glucose and Glycated hemoglobin? J. Diabet. Sci. Technol. 5(6): 1572 - 1583. https://doi. org/10.1177/193229681100500634

- McMurray CH,Blanchflower WJ, Rice DA (1984). Automated kinetic method for D-3-hydroxybutyrate in plasma or serum. Clin. Chem. 30(3): $421-425$.

- Misra S, Oliver NS (2015). Diabetic ketoacidosis in adults. BMJ. 351: h5660. https://doi.org/10.1136/bmj.h5660

- Nair M, Prabhakaran D, Venkat Narayan KM, Sinha R, Lakshmy R, Devasenapathy N, Daniel CR, Gupta R, George PS, Mathew A, Tandon N, Reddy KS (2011). HbA1c values for defining diabetes and impaired fasting glucose in Asian Indians. Prim. Care Diabet. 5(2): 95 - 102. https://doi. org/10.1016/j.pcd.2011.02.002

- Nathan DM, Turgeon H, Regan S (2007). Relationship between Glycated hemoglobin levels and mean glucose levels over time. Diabetologia. 50(11): 2239 - 44. https:// doi.org/10.1007/s00125-007-0803-0

- Penno G, Solini A, Bonora E, Fondelli C, Orsi E, Zerbini G, Morano S, Cavalot F, Lamacchia O, Laviola L, Nicolucci A, Pugliese G, Renal Insufficiency and Cardiovascular Events (RIACE) Study Group (2013). HbA1c variability as an independent correlate of nephropathy, but not retinopathy, in patients with type 2 diabetes. Diabet. Care. 36(8): 2301 2310. https://doi.org/10.2337/dc12-2264

- Simmons JH, Chen V, Miller KM, McGill JB, Bergenstal RM, Goland RS, Harlan DM, Largay JF, Massaro EM, Beck RW, T1D Exchange Clinic Network (2013). Differences in the management of type 1 diabetes among adults under excellent control compared with those under poor control in the T1D Exchange Clinic Registry. Diabet. Care. 36(11): 3573 - 3577. https://doi.org/10.2337/dc12-2643

- Snehalatha C, Ramachandran A, Satyavani K, Vijay V (2000). 
Limitations of glycosylated haemoglobin as an index of glucose tolerance. Diabet. Res. Clin. Pract. 47(2): 129 - 133.

- Trief PM, Xing D, Foster NC, Maahs DM, Kittelsrud JM, Olson BA, Young LA, Peters AL, Bergenstal RM, Miller KM, Beck RW, Weinstock RS, T1D Exchange Clinic Network (2014). Depression in adults in the T1D exchange clinic registry. Diabet. Care. 37(6): 1563 - 1572. https://doi. org/10.2337/dc13-1867

- Umpierrez GE, Woo W, Hagopian WA, Isaacs SD, Palmer JP, Gaur LK, Nepom GT, Clark WS, Mixon PS, Kitabchi AE (1999). Immunogenetic analysis suggests different pathogenesis for obese and lean African-Americans with diabetic ketoacidosis. Diabet. Care. 22(9): 1517 - 1523.

- Waden J, Forsblom C, Thorn LM, Gordin D, Saraheimo M, Groop PH (2009). A1C variability predicts incident cardiovascular events, microalbuminuria, and overt diabetic nephropathy in patients with type 1 diabetes. Diabetes. 8(11): 2649 - 2655. https://doi.org/10.2337/db09-0693

- Zhu B, Bu L, Zhang M, Gusdon AM, Zheng L, Rampersad S, $\mathrm{Li} \mathrm{J,} \mathrm{Qu} \mathrm{Shen} \mathrm{(2016).} \mathrm{HbA1c} \mathrm{as} \mathrm{a} \mathrm{screening} \mathrm{tool} \mathrm{for} \mathrm{ketosis}$ in patients with type 2 diabetes mellitus. Sci. Rep. 6: 39687. https://doi.org/10.1038/srep39687 